\title{
Select documents: Sir James Ware's bibliographic lists
}

\begin{abstract}
A $t$ first glance the low yield of books produced by the Dublin printing presses for circulation in early Stuart Ireland could lead to two hasty conclusions: first, that Irish society was unreceptive towards reading; and second, that the printing presses had to contend with a very small (literate) target audience. ${ }^{\text {Y }}$ Yet nothing could be further from the truth. In recent years Raymond Gillespie has done much to dispel these suppositions. ${ }^{2}$ His appraisal of English port books, printing press accounts from the continent and library borrowing lists plainly demonstrates the appetite of an interested reading public in Ireland. ${ }^{3}$ The value of analysing book loaning lists was further underlined by William O'Sullivan when he partially revealed the borrowing records belonging to the historian and antiquarian, Sir James Ware. ${ }^{4}$ In so doing, he drew attention to the potential of a deeper exploration of Irish cultural and intellectual life.

It would be misleading to claim that Ware's scholarly career has been underestimated. Any study involving cultural history in seventeenth-century Ireland inevitably contains references to his works or manuscripts. However, despite the widely acknowledged calibre of his scholarship there remains to date no thorough study of his contribution. This is all the more surprising in view of the fact that many of his contemporaries such as Archbishop James Ussher, Mícheál ó Cléirigh O.F.M., Geoffrey Keating and Luke Wadding O.F.M. have been comprehensively examined. ${ }^{6}$ How Ware's career continues to be overlooked
\end{abstract}

${ }^{1}$ E. R. McClintock Dix, Catalogue of early Dublin-printed books, 1601 to 1700: part I, 1601 to 1625; part 11, 1626 to 1650 (Dublin, 1898-9).

2 Raymond Gillespie, Reading Ireland: print, reading and social change in early modern Ireland (Manchester, 2005); idem, Seventeenth-century Dubliners and their books (Dublin, 2005); idem, 'The circulation of print in seventeenth-century lreland' in Studia Hibernica, xxix (1995-97), pp 31-58; idem, 'Irish printing in the early seventeenth century' in Irish Economic and Social History, xv (1988), pp 81-8.

${ }^{3}$ Raymond Gillespie, 'Borrowing books from Christ Church Cathedral Dublin, 1607' in Long Room, xliii (1998), pp 15-19. See also Elizabethanne Boran, 'The libraries of Luke Challoner and James Ussher, 1595-1608' in Helga Robinson-Hammerstein (ed.), European universities in the age of Reformation and Counter Reformation (Dublin, 1998), pp 109-15.

${ }^{4}$ William O'Sullivan, 'A finding list of Sir James Ware's manuscripts' in Proceedings of the Royal Irish Academy, Section C, xcvii (1997), pp 71-2.

5 O'Sullivan, 'A finding list of Sir James Ware's manuscripts', pp 69-77; Mark Empey, "Value-free" history? the scholarly network of Sir James Ware" in History Ireland, xx, no. 2 (Mar/Apr. 2012), pp 20-3; Philip Wilson, 'The writings of Sir James Ware and the forgeries of Robert Ware' in Transactions of the Bibliographical Society, xv (1920), pp 83-94.

${ }^{6}$ Alan Ford, James Ussher: theology, history, and politics in early-modern Ireland and England (Oxford, 2007); Nollaig Ó Muraíle (ed.), Mícheál ó Cléirigh, his associates and 
is therefore something of a mystery. Over a forty-year period, from his first publication on the succession of the archbishops of Cashel and Tuam in 1626 to his final opus on the bishops of Ireland in 1665, Ware produced eleven historical works. To these publications one must add nearly thirty surviving manuscripts from his personal collection which reveals both the scope and depth of his research. Consequently, the reproduction of Ware's bibliographic lists provides an opportunity to redress some of the lacunae in current historiography? In particular, they serve a broader purpose which underscores the importance of investigating Ware. They show the extent of his knowledge of historical sources in Ireland and the wider European world. These included medieval manuscripts, some of which were composed in Irish, Anglo-Irish manuscripts, as well as recently published works that were mainly from continental Europe. Above all, however, the lists shed further light on the rapidly changing social and cultural dynamics in Ireland.

There are three lists in question. Two of them are taken from MS 6404 in Trinity College, Dublin. The lists on folios $85 \mathrm{r}$ and $85 \mathrm{v}$ consist chiefly of registers, chronicles and annals that Ware identified as 'books to be enquired after', dated sometime between 1619 and $1622 .{ }^{8}$ Folio $168 \mathrm{r}$, dated 15 December 1625 , concerns a considerable number of printed works. This particular folio is highly significant because it is no longer possible to consult it on account of the frailty of the spine. The third list in British Library, Additional Manuscript 4821, relates to books that he endeavoured to purchase in 1632, 1633 and 1638 . In this context it may be observed that Ware understood 'book' to mean both manuscript and printed material. While the contemporary understanding of the term could apply to a wide range of manuscript sources, Ware was concerned with composite manuscripts such as registers and annals that were almost certainly bound in book form. ${ }^{9}$

The fortuitous survival of these bibliographic lists raises a host of fascinating questions, not least the issue of why Ware purchased the books. It is clear from the 1625 list that several works related to his current research. His acquisition of Aubert Miraeus's Chronicion Cisterciensis Ordinis and his request for

St Anthony's College Louvain (Dublin, 2008); Bernadette Cunningham, The Annals of the Four Masters (Dublin, 2010); eadem, The world of Geoffrey Keating: history, myth and religion in seventeenth-century Ireland (Dublin, 2000); Franciscan Fathers (eds), Father Luke Wadding: commemorative volume (Dublin, 1957).

${ }^{7}$ In addition to the bibliographic lists produced below, there are also two very rough drafts compiled by Ware which recorded manuscripts and books he loaned to friends between circa 1625 and 1631: B.L., Additional MS 4821, ff 239r, 242r.

${ }^{8}$ This is based on the references to Adam Loftus, appointed lord chancellor in 1619 , and Robert Rothe who died in 1622, and to the date of Sir Oliver Tuite's baronetcy, 16 June 1622: Terry Clavin, 'Loftus, Adam (1568?-1643), 1st Viscount Loftus of Ely' and Terry Clavin, 'Rothe, Robert (1550-1622), both in D.I.B.; Charles Mosley (ed.), Burke's peerage, baronetage and knightage (107th edition, 3 volumes, Wilmington, 2003) iii, 3954.

${ }^{9}$ Oxford English Dictionary. 
Crisóstomo Henriques's Fasciculus Sanctorum ordinis Cisterciensis (Ware mistakenly entitled this 'Constantia Catholica') can be traced to Ware's work on the obits of the archbishops of Cashel and Tuam, which included an appendix on the Cistercian monasteries in Ireland.$^{10}$ Likewise Petrus Cratepoil's compilation of the bishops of Cologne and Trier and Ambrosio Gozzeo's catalogue of famous scholars in the Dominican order exhibit similar patterns in both structure and content to Ware's first two publications." That he explored the same themes was no accident. His object was to promote Ireland's historical past while simultaneously securing the country's position in the ranks of other European kingdoms. Thus, Ware was participating in a much broader project that had been initiated by European scholars in the sixteenth century.

Whereas the choice of books may have an obvious connection with work in progress, they also disclose his specific scholarly ambitions for the future. His awareness that Daniel Molyneux, Ulster King of Arms, had in his possession Meredith Hanmer's collections is noteworthy. Hanmer's 'Chronicle of Ireland' formed part of Ware's edited work entitled The Historie of Ireland in 1633, better known for its inclusion of Edmund Spenser's 'View of the State of Ireland'.12 Indeed, Ware's shift in interest from ecclesiastical history in the 1620 s to the study of antiquities in and beyond the 1630s is indicated by his expressed desire to obtain Richard Verstegan's study of Anglo-Saxon scholarship and David Rothe's vociferous attack on Thomas Dempster's claims that Irish saints were in fact Scottish. ${ }^{13}$ These, in addition to his attraction to the influential works of Philip O'Sullivan Beare, would have been important ports of call for Ware's masterpiece, De Hibernia et antiquitatibus eius disquisitiones (London, 1654). Meanwhile, Thomas Gratianus's assessment of the writers from the Augustinian order served as a particularly apposite exemplar for Ware in his compilation of writers of Ireland which he published in $1639 .{ }^{14}$

If printed books gave shape to his publications then the manuscript books he enquired about provide a comparable insight into the thoroughness of his research. Ware clearly placed considerable emphasis on registers, chronicles and annals, signifying the extent to which he relied on them for examining Irish history. Moreover, the bibliographic lists reveal the scope and variety of sources that were fundamental to his scholarly pursuits. As an apprentice in the auditor general's office he had privileged access to monastic registers which included

10 James Ware, Archiepiscoporum Cassiliensium et Tuamensium vitae ... quibus adijcitur historia Coenobiorum Cisterciensium Hiberniae (Dublin, 1626).

${ }^{1]}$ Ibid.; James Ware, De Praesulibus Lageniae sive provinciae Dubliniensis (Dublin, 1628 ).

${ }^{12}$ Sir James Ware (ed.), The Historie of Ireland, collected by three learned authors (Dublin, 1633). It is worth noting that Molyneux's editorial skills came in for sharp criticism from Hanmer's nephew, John Hanmer, bishop of St Asaph. Writing to Ussher, Hanmer complained about the discovery of some defects "not only in orthography, by reason of the unskilfulness of the transcriber, but also in the sense, by reason of dissonancy in the coherence and the very context itself.' Hanmer to Ussher, 28 May 1627 in The whole works of the most Rev. James Ussher, ed. C. R. Elrington (17 vols, Dublin, 1847-64), XV, 378.

${ }^{13}$ On Dempster's provocative claims sce his posthumous work Historia ecclesiastica gentis Scotorum (Bologna, 1627).

${ }^{14}$ Sir James Ware, De Scriptoribus Hiberniae (Dublin, 1639). 
essential information in the form of deeds and the transfer of land. ${ }^{15}$ On the other hand, the chronicles owned by native Irishmen, which offered a narrative of Irish events, were likely to have been composed in the vernacular. Ware was able to read Irish, although probably not as early as $1622 .{ }^{16}$ However, he was able to compensate for his limited knowledge of the language by employing translators such as Muircheartach $O$ Cionga and Dubhaltach Mac Fhirbhisigh. ${ }^{17}$ Neither the linguistic barrier nor supposed prejudices towards an Irish version of affairs inhibited Ware's investigations.

While the connections between his research and the books he purchased or requested deserve to be stressed, items of more general interest to Ware are worthy of note too. John Selden's study of English law and constitutional history, for example, served to broaden both his personal and intellectual curiosities. In his address to the reader Selden stated: 'historicall tradition of use, and succinct description of ceremony, are my ends; both deduced from the auncients, but without proselenique affectation' ${ }^{18}$ There are other peculiar acquisitions such as Mundus Jovialis by the German astronomer, Simon Marius, who gave a detailed account of Jupiter and its moons. Ware certainly had a taste for astronomy as evidenced by his diary, where he regularly records shooting stars and comets. ${ }^{19}$ He also singled out books that were more obviously concerned with current affairs such as Jacques Isnard's French commentary on the duke of Buckingham's failed invasion of St-Martin-de-Ré in 1627. The expedition to western France was always going to appeal to Ware's royalist sympathies, but given his increased role in government business by the end of the 1620 s, Isnard's account may well have been useful in keeping abreast of political developments. ${ }^{20}$

Most intriguing of all, however, is his attraction to religious controversy. Among the books he sought to buy in 1632 was Declaratio Catholicorum laicorum Angliae circa authoritatem quam reumus Dominus Episcopus Chalcedonensis. This was an attack by the Catholic nobility and gentry of England on the titular bishop of Chalcedon, Richard Smith, who attempted to exercise full jurisdictional authority over the secular and regular clergy. Whereas

${ }^{15}$ Having procured the reversion of the office of auditor general in 1613, Ware did not inherit the position until his father's death in 1632 (T.C.D., MS 6404, ff 97v, 115r).

${ }^{16}$ Roderick O'Flaherty to Edward Lhwyd, April 1708 (Bodl., MS Ashmole 1817a, f. 57r). See also, Richard Sharpe (ed.), Roderick O'Flaherty's letters to William Molyneux, Edward Lhwyd and Samuel Molyneux, 1696-1709 (Dublin, 2013), pp 32, 325.

17 B.L., Add. MS 4797, fol. 88v; B.L. Add. MS 4799, fols 45r-70r. See also John T. O'Donovan, 'The Annals of Ireland, 1443-1468 translated from lrish by Dudley Firbisse' in The miscellany of the Irish Archaeological Society, volume I (Irish Archaeological Society, Dublin, 1846), pp 198-302; Nollaig Ó Muraile, The celebrated antiquary: Dubhaltach Mac Fhirbhisigh (c. 1600-1671): his lineage, life and learning (Maynooth, 2002), pp 247-63.

${ }^{18}$ John Selden, The duello, or single combat (London, 1610), p. A2v.

${ }^{19}$ T.C.D., MS 6404, ff 62v, 108v, $121 \mathrm{r}$; B.L., Additional MS 4784, f. $251 \mathrm{r}$.

20 'A Journall touching the voyage in to the Ile of Ree in 1627' (Bodl., MS Rawlinson B 480, ff 33r-42v). Ware marked his political career when he was chosen as a special envoy with Sir John Bingley to attend the English privy council on government business. See: Instructions from the lord deputy and council to the English privy council, 25 Feb. 1629 (Cal. S. P., lre., 1625-32, p. 434). 
the religious orders deeply resented being under the control of a bishop, the laity viewed Smith's plans as a threat to their property and safety. The penal laws imposed by the government had forced members of the Catholic gentry to shelter priests, thus making the clergy more dependent on them. More to the point, Smith's designs had brought unwelcome attention to the wider Catholic community. ${ }^{21}$ The circumstances in Ireland, where the Franciscan archbishop of Dublin, Thomas Fleming, was coming under fierce criticism from the secular clergy in his diocese, were no different. Furthermore, this contretemps had escalated in 1632 with a series of printed outbursts against Fleming. ${ }^{22}$ It is quite possible that Ware endeavoured to keep himself sufficiently informed about the wider conflict that was endangering the stability of Catholicism in Britain and Ireland.

That he succeeded in obtaining a copy of the Declaratio is noteworthy. In an attempt to ease mounting tensions its circulation was restricted within Catholic circles (its main target audience), having being labelled as one of the "forbidden bookes' ${ }^{23}$ This leads to another important question: how did Ware acquire books, especially those which may have proved difficult to get? His source for purchasing continental works was Europe's major book fair at Frankfurt, held every spring and autumn. ${ }^{24}$ By consulting the bi-annual Frankfurt catalogue, to which he had access in either Trinity College library or the Society of Stationers (the king's printers in Ireland), Ware was cognisant of the latest intellectual debates and disputations in continental Europe. ${ }^{25}$ His association with the Society

${ }^{21}$ At the forefront of the protestation was the former secretary of state, George Calvert, baron Baltimore (an Irish title). See Michael C. Questier (ed.), Newsletters from the Caroline court, 1631-1638: Catholicism and the politics of the personal rule (Camden Society, 5th series, xxvi, 2005), p. 4; J. D. Krugler, English and Catholic: the Lords Baltimore in the seventeenth century (Baltimore, 2004), pp 114-15.

22 Peter Caddell and Paul Harris, To the most illustrious archbishops and reverend bishops of Ireland, but more particularly to those of the province of Dublin their honourable lords, David Bishop of Osory, John of Fernes, Ross of Kildare, and Mathew Vicar Apostolicall of Laghlein (Roan, at the sign of the three lilies with Edmund Fitzours [i.e. Dublin Society of Stationers], 1632); Paul Harris, The excommunication published by the L. archbishop of Dubin Thomas Flemming alias Barnwell friar of the Order of $S$. Francis, against the inhabitants of the diocesse of Dublin, for hearing the masses of Peter Caddell D. of Divinity, and Paul Harris priests, is proved not onely injust, but of no validity, and consequently binding to no obedience (Dublin, 1632). On the dispute between the secular and regular clergy in Ireland see Thomas O'Connor, Irish Jansenists, 1600-70: religion and politics in Flanders, France, Ireland and Rome (Dublin, 2008), pp $149-70$.

${ }^{23}$ Clerk [John Southcot] to [Peter Biddulph], 20 Jan. 1632 in Questier (ed.), Newsletters from the Caroline court, 1631-1638, p. 46: 'I suppose amongst other forbidden bookes you will gett the lay Cath[olics'] Declaration'.

${ }^{24}$ On the Frankfurt book fair see Andrew Pettegree, The book in the Renaissance (New Haven, 2010), pp 78-82; James Westphal Thompson (ed.), The Frankfort book fair: the Francofordiense Emporium of Henri Estienne (Chicago, 1911).

${ }^{25}$ It was very likely that Trinity library purchased the bi-annual catalogues for the purpose of improving and updating its holdings. In the 1620s, Ware compiled an extensive list of books that were of interest to him from Trinity's library catalogue. Among the items he identified was the Frankfurt book catalogue between the years 1592 and 1600, which suggests that Ware regularly used the library to gain access to material he could not otherwise acquire (B.L., Add. MS 4821, f. 72v). 
was therefore crucial. Located near his Dublin residence on Castle Street, the printers had direct links with the Frankfurt book fair. They regularly ordered foreign items and possibly sold copies printed in Dublin for wider dissemination. For Ware, then, the Society provided a valuable outlet for purchasing the latest printed books relevant to his research. Of course, it was a mutually beneficial arrangement. The printers profited from Ware as a customer as well as a writer who chose to publish with them. The 1625 list certainly suggests that he was on very good terms with the Society. Having received all eleven books or catalogues Ware had yet to pay Bartholomew Downes, one of the king's printers, for his new acquisitions.

Considering that Ware's scholarly career was at a relatively early stage, his grasp of available source material was impressive. No less remarkable was his wide knowledge of a circle of people who possessed works beyond the institutional or university library. A cursory examination of the list of manuscript books which he enquired after reveals a notable geographic spread of people. In Connacht, for example, Ware knew that the Dominican Manus McAward and the prominent landlord Sir John King, as well as Hugh Roe Farrell from Longford, held material that was fundamental to his research. In Ulster, he identified sources that were in the hands of his friend and colleague, Daniel Molyneux, as well as Bishops Thomas Moigne of Kilmore and Andrew Knox of Raphoe. ${ }^{26}$ Similarly, George Andrews, dean of St Mary's cathedral in Limerick, held the cathedral register and the register of the vicars choral containing information on obits. ${ }^{27}$ Other books of obits in the former monasteries of Adare in County Limerick and Timoleague in County Cork were presumably retained by the landhoider. Finally, in Leinster Ware knew that Garret Moore of Louth, Carolus O'Doran of Wexford, Sir Nicholas Whyte of Kildare, and the Rothes of Kilkenny (to mention but a few) preserved items that were relevant to the history of the locality. Perhaps the most conspicuous references in the list relate to collectors of Irish manuscripts who resided in England: Sir Henry Bourchier and Sir Robert Cotton. Both men treasured Irish sources. Bourchier was a graduate of Trinity College before moving to England in the early 1620 s. His widow donated $£ 200$ to improve the library's holdings. ${ }^{28}$ Cotton possessed one of the most extensive private collections in Europe, including many manuscripts of Irish interest such as the letters of Giraldus Cambrensis.

The diversity of the ownership of Irish manuscripts is especially striking. By the same token it helps to explain the difficulties that Ware encountered in accessing material. This raises another important question: why was the possession of manuscript books so highly prized by families living in Ireland?

\footnotetext{
${ }^{26}$ Ware shared a very close relationship with Molyneux, who was a keen genealogist of Gaelic families. In 1628, he thanked Molyneaux for loaning him the canons of the synod convened by the bishop of Ferns, John St. John, between 1223 and 1243: Ware, De Praesulibus Lageniae, p. 57.

${ }^{27}$ Andrews was another useful contact. In November 1624 he transcribed a copy of the catalogue of St Mary's cathedral library for Ware (Bodl., MS Rawl. B 480, ff 69r-78r).

${ }^{28}$ Victor Stater, 'Bourchier, Henry, fifth earl of Bath (c.1587-1654)', in Oxford D.N.B.
} 
There are a number of possibilities. First, they were likely to have been viewed as family heirlooms. The registers, in particular, had been in their possession as a consequence of securing lands following the dissolution of the monasteries in the $1530 \mathrm{~s}$. Second, these historical sources contained genealogies that could be used to augment their social standing. In a society where the political and cultural frontier was becoming increasingly blurred as a result of sustained peace and economic improvement, such manuscripts could be useful as a means of confirming family identities which was coming under threat. ${ }^{29}$ It is credible, moreover, that the ancestors of Farrell, O'Doran and Mac Anave were members of learned families who commissioned the production of the Irish chronicles. For example, the O'Dorans were an established law family who were prominent in counties Wexford and Laois. ${ }^{30}$ Finally, and most significantly, the manuscript books served as legal resources. The Ulster plantation signalled the government's intent of introducing new settlers and further private enterprises in Leitrim, Longford and Wexford, an indication that this policy was set to continue. ${ }^{31}$ Indeed, Wicklow, Ormond and Connacht were strongly rumoured as future targets - areas where both native Irish and Old English families were set to lose out. ${ }^{32}$ Thus Patrick Den of Grenane, Brien Cavenagh of Wicklow, and Mac Anave, whose family were prominent in western Connacht, could exploit such manuscripts to support their land title claims.

Although the archives at Trinity College and Dublin Castle were well stocked with historical sources, Ware still needed to develop his bibliographic profile by relying on an eclectic group of dignitaries. As a committed Protestant, he would not encounter problems in obtaining registers from Church of Ireland bishops. Equally his father's occupation as auditor general meant that he had ready access to members of the administration such as the solicitor general, Edward Bolton, and the lord chancellor, Adam Loftus. Above all, Ware's list plainly demonstrates that the perceived ethnic and religious divisions, which shape our views of seventeenth-century Ireland, were easily penetrated. His unhindered contact with members of the native Irish and Old English communities shows that he had no inhibitions about borrowing material from them. More to the point, they were happy to allow him to consult their manuscript books. This is all the more remarkable in view of the fact that Ware was still a relatively unproven historian (he only had a bachelor's degree from Trinity College). The evidence, therefore, points to a high degree of mutual trust.

29 See, for example, N. J. A. Williams (ed.), Pairlement Chloime Tomáis (Dublin, 1981), pp 83, 96-8.

30 Nerys Patterson, 'Gaelic law and the Tudor conquest of Ireland: the social background of the sixteenth-century recensions of the pseudo-historical Prologue to the Senchas már' in Irish Historical Studies, xxvii, no. 107 (May, 1991), pp 204-14.

${ }^{31}$ Brian Mac Cuarta, 'The plantation of Leitrim, 1620-41' in Irish Historical Studies, xxxii, no. 127 (May, 2001), pp 297-320; Rolf Loeber and Magda Stouthamer-Loeber, 'The lost architecture of the Wexford Plantation' in Kevin Whelan (ed.), Wexford: history and society (Dublin, 1987), pp 173-200.

${ }^{32}$ Lord Esmonde to the Lord Dorchester, 9 May 1630 (Cal. S. P. Ire., 1625-32, p. 536); Sir Arthur Tyringham to Dorchester, 26 May 1631 (ibid., p. 612): Archbishop Ussher to Archbishop Laud, 22 Sept. 1631 (ibid., p. 631); Viscount Falkland to Sir James Dillon, 2 Jan.1633 (Falkland Letter Book, 1629-31, N.A.1., M 2445, f. 279); Falkland to Sir William Parsons, 18 Feb. 1633 (ibid., f. 286); Falkland to Viscount Ranelagh, 3 Mar. 1633 (ibid., f. 290). 
The exchange of historical sources serves a broader purpose in analysing Irish society. First, it provides a useful context to challenge the view that seventeenth-century Ireland was a kingdom segregated by ethnicity and religion. Polarisations naturally occurred when tensions rose with the outbreak of war. But when there were sustained periods of peace prior to the $164 \mathrm{l}$ rebellion, and again after the Restoration, these perceived divisions are less clearly defined..$^{33}$ The scholarly network that Archbishop James Ussher created was reliant on intimate relationships with men who shared neither his political nor religious convictions. ${ }^{34}$ Ware was no different. His dealings with Dominican friars, Catholic bishops, native Irishmen, Old Englishmen and government officials underline the degree of co-operation and collaboration that existed within a broad spectrum of individuals. This was, moreover, a twoway process. Ware's continually expanding library meant that he was an essential contact for anyone with an informed interest in political, religious or cultural history. ${ }^{35}$ This leads to the second point. The lists shed further light on the extent to which Irish society was culturally active. On the one hand, Ware's accumulation of sources for personal research coincided with the pioneering work of Catholic scholars such as Geoffrey Keating and the 'Four Masters' led by Mícheál ó Cléirigh. On the other hand, it reflected a wider appetite for, and appreciation of, history among the reading public. Such tastes were not confined exclusively to a growing interest in Ireland's history, but also extended to a hunger for comparable studies from the continent. In other words, Irish society was far from being on the periphery of intellectual Europe. If anything, it was as much in touch with the mainstream European norms as any other kingdom.

\section{III}

By overlooking Ware's career, historians have missed the opportunity to examine one of the greatest scholars in his day in Ireland. There can be little doubt that much can be gleaned from his contribution and achievements. The books that he purchased illustrate how exhaustive and detailed his research was. They show how he endeavoured to bring Irish antiquities into line with the norms of European scholarship, thereby raising the historical profile of Ireland internationally. He set a high standard for others to follow; not least by scouring the length and breadth of the country in search of ancient sources. Crucially, this included both Latin and Irish material, marking a new departure in Irish Protestant attitudes to the country's past. The success of his endeavours depended on the co-operation and trust of a variety of people which criss-crossed ethnic, religious and political boundaries. That he

33 Bernadette Cunningham and Raymond Gillespie, 'Cultural frontiers and the circulation of manuscripts in Ireland, $1625-1725$ ' in James Kelly and Ciarán Mac Murchaidh (eds), Irish and English: essays on the Irish linguistic and cultural frontier, 1600-1900 (Dublin, 2012), pp 58-95.

34 Bernadette Cunningham and Raymond Gillespie, 'James Ussher and his Irish manuscripts' in Studia Hibernica, xxxiii (2004-2005), pp 81-99.

${ }^{35}$ B.L., Add. MS 4821, ff 236v, 239r. 
succeeded is a testament not only of Ware's determination but also the shared cultural ambitions of Irish society in the seventeenth century. ${ }^{36}$

MARK EMPEY Department of History, National University of Ireland, Maynooth

${ }^{36}$ I would like to express my gratitude to the National University of Ireland for their generous financial assistance which has enabled me to pursue my research. I am also very grateful to Professor Raymond Gillespie for his comments and suggestions on an earlier draft. 


\section{Trinity College Dublin, MS 6404}

\section{[f. 85r]}

Books to be enquired after

\# Annales dom[us] fr[atru]m Praedicator[um] Athenriae with Man[us] Mc

Award, an old friar there ${ }^{37}-$ he died $1626^{38}$

Registrum Mon[aster]ii Buelliensis with Sir John King ${ }^{39}$

Registrum Mon[aster] ii de Mellifont with the Lo[rd] Moore ${ }^{40}$

Chronicon Hibernic[um] with Hugh Roe Farrell

Al[ter] Chron[icon] Hib[ernicum] with Carol[us] O Doran

Al[ter] Chron[icon] Hib[ernicum] with [blank] Mac A Nave

$<\operatorname{Legi}^{4}>$ \# Reg[ist]r[u]m Lim[er]ic[ensis] with Mr Deane Andrews ${ }^{42}$

\# + Reg[ist]r[u]m ecc[lesi]ae Kilmorensis with the Bishop thereof ${ }^{43}$

$+\operatorname{Reg}\left[\right.$ ist]r[u]m ecc[lesi]ae Rapotensis with the $B$ [isho]p thereof ${ }^{44}$

\# Reg[ist]r[u]m ecc[lesi]ae Elfinen[ensis] with the Bishop thereof ${ }^{45}$

+ Epistolae MSS Gir[aldus] Cambrensis [with] Sir Rob[ert] Cotton ${ }^{46}$

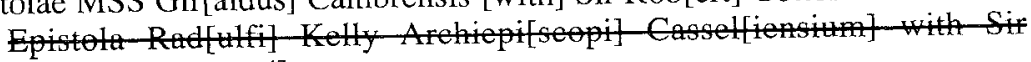

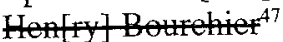

\# Dr Hanm[er]s collections with Mr Dan[iel] Molyneux ${ }^{48}$

${ }^{37}$ For Ware's copy see B.L., Add. MS 4784, fols 8r-19r. McAward appears in a lease made by the town officials on 20 May 1623: M. J. Blake, Blake family records, 1600-1700 (London, 1905), pp 30-1.

${ }^{38}$ Inserted in different ink.

${ }^{39}$ Possibly the annals of Boyle, B.L., Cotton MS Titus A. XXV; A. Martin Freeman (ed. and trans.), 'The annals in Cotton MS Titus A. XXV' in Revue Celtique, xli (1924), pp 301-30; xlii (1925), pp 283-305; xliii (1926), pp 358-84; xliv (1927), pp 336-61. Sir John King had extensive landholdings that incorporated the site of the former Cistercian abbey at Boyle where he acted as constable: Anthony M. McCormack, 'King, Sir John (d. 1637)' in D.I.B.

${ }^{40}$ Inserted in different ink. Terry Clavin, 'Moore, Sir Garret (c.1566-1627), first Viscount Moore of Drogheda' in D.I.B.

41 'Gathered' or 'collected'.

42 This was presumably the Black Book of Limerick which Ware consulted: B.L., Add. MS 4787, ff 71r-72r; Bodl., MS Rawlinson B 484, fol. 41v; The Black Book of Limerick ed. James MacCaffrey (Dublin, 1907). Andrews was dean of Limerick and precentor of St Patrick's cathedral (1603-35) and later bishop of Ferns and Leighlin (1635-48): Helen Andrews, 'Andrews, George (c.1575-1648)' in D.I.B.

${ }^{43}$ Thomas Moigne (d. 1629), bishop of Kilmore (1613-29): Sir F. Maurice Powicke and E. B. Fryde (eds), Handbook of British chronology (2nd edn, London, 1961), p. 359.

${ }^{44}$ Andrew Knox, bishop of Raphoe (1610-33): Alan Ford, 'Knox, Andrew (1559-1633)' in D.I.B.

45 Ware made some notes in B.L., Add. MS 4791, fols 108r-108v. Edward King was bishop of Elphin 1611-39: Ciaran Diamond, 'King, Edward (c.1576-1639)' in Oxford D.N.B.

${ }^{46}$ Sir Robert Cotton, English antiquarian and politician: Stuart Handley, 'Cotton, Sir Robert Bruce, first baronet (1571-1631)' in Oxford DN.B.

47 When Ware published the obits of the archbishops of Cashel and Tuam in 1626 he noted in the entry for Archbishop Ralph Kelly that the letters were no longer extant: Ware, Archiepiscoporum Cassiliensium et Tuamensium vitae, pp 18-19.

${ }^{48}$ Daniel Molyneux was Ulster King of Arms and principal herald of the kingdom of Ireland: Terry Clavin, 'Molyneux, Daniel (1568-1632)' in D.I.B. 
Divers manuscripts with John Doyle

+ dire

The Provisor of the Coll[ege] of Kilmallock - Reg[iste]r of the Collegiate church there

Divers manuscripts with Mr Brien Cavenagh ${ }^{49}$

< Legi> \# The Register of Kells with David Rowth P[raesulibus] Ossor[iensis] ${ }^{50}$

The Annals of Clonmel - vid[e] Edw[ard] Bolton in Speed ${ }^{51}$

The Register of Monasterevin with the Lord Chancellor ${ }^{52}$

$<$ Legi $>+$ The Earl of Kildare's Register ${ }^{53}$

The Lo[rd] of Slane's Register ${ }^{54}$

The Lo[rd] Roche's Reg[ister] ${ }^{55}$

The Tuit's Reg[iste]r with Sir Oliver Tuite ${ }^{56}$

$<$ Legi> The Visc[ount] Gormanston's Reg[iste]r [in pencil] ${ }^{57}$

$<$ Legi $>$ + Annals of Friar Clynne with Robert Rothe of Kilkenny ${ }^{58}$

Kilconnel1 ${ }^{60}$ Legi XGalway ${ }^{59}$

Liber obitum convent deAdare ${ }^{61}\{$
Kildare

:

${ }^{49}$ This entry is written in pencil.

50 David Rothe was Catholic bishop of Ossory between 1618 and 1650: Thomas O'Connor, 'Rothe, David (1573-1650)' in D.I.B.

${ }^{51}$ Edward Bolton was appointed solicitor general for Ireland on 5 February 1622: Robert Armstrong, 'Bolton, Edward (1592-1659)' in DI.B. In the margin Ware makes a note: 'Jo[hn] f[it]z Tho[mas] dwelt at Rathangan at 1288'.

${ }^{52}$ Adam Loftus, whose main estate in Monasterevin incorporated the twelfth-century Cistercian monastery of Moore Abbey: Clavin, 'Loftus, Adam'.

${ }^{53}$ Probably the Red Book of Kildare, B.L., Harley MS 3758. This was most likely in the possession of the sixteenth earl of Kildare: Michéal Ó Siochrú, 'Fitzgerald, George (1612-60), 16th earl of Kildare' in D.I.B.

${ }^{54}$ William Fleming, fourteenth Baron Slane: see Michéal Ó Siochrú, 'Fleming, William (c. 1611? -1642), 14th Baron Slane' in D.I.B.

${ }^{55}$ David Roche (b. before 1588-1635), seventh Viscount Roche of Fermoy: Mosley (ed.), Burke's peerage, baronetage and knightage, ii, 2238.

${ }^{56}$ Sir Oliver Tuite (c. 1588-1642) of Sonnogh, County Westmeath: Mosley (ed.), Burke's Peerage, Baronetage \& Knightage, iii, 3954.

${ }^{57}$ For Ware's copy see B.L., Lansdowne MS 418, ff 43r-45v. See also Calendar of the Gormanston Register circa 1175-1397, eds James Mills and M. J. McEnery (Dublin, 1916); Anthony M. McCormack and Terry Clavin, 'Preston, Jenico (Genico) (1585-1630), 5th Viscount Gormanston' in D.I.B.

${ }^{58}$ For Ware's copy see B.L., Add. MS 4789, ff 99v-102v; Bodl., MS Rawl. B 496, ff 44r-70r. The original Rothe transcript is in the Dublin City Library, Gilbert MS 105 in which Rothe states that he obtained the original copy from a fellow Kilkenny native, Richard Shee. Robert Rothe, lawyer and antiquarian, was a cousin of Bishop David Rothe: see above, note 8 .

${ }^{59}$ For Ware's copy see B.L., Add. MS 4793, ff 145r-146v.

${ }^{60}$ The chapter book of Kilconnell is mentioned by Donatus Mooney, minister provincial of the Irish Franciscans, who made an official visitation of the Franciscan friaries in Ireland between 1615 and 1617. See Brendan Jennings, 'Brussels MS. 3947: Donatus Moneyus, De Provincia Hiberniae S. Francisci' in Analecta Hibernica, vi (Nov. 1934), p. 56.

${ }^{61}$ Ware may have obtained this at a later stage. See B.L., Add. MS 4791, ff 153r-154r. 
Donegal

Timol[e]ag[ue]

Missale de Iniscorthy with $\mathrm{Mr}$ Hore ${ }^{62}$

Liber statutoru[m] ord[inis] minoru[m] in Hib[er]nia

Liber de Idinnyn

$\operatorname{Reg}[$ ist $] \mathrm{r}[\mathrm{u}] \mathrm{m}$ Vicarioru[m] Choraliu[m] Limeric[ensis $]^{63}$

Reg[ist $] \mathrm{r}[\mathrm{u}] \mathrm{m}$ Conall with Sir Nicholas Whyte ${ }^{64}$

\section{[f. 168r]}

Debts to $\mathrm{Mr}$ Downes ${ }^{65}$ for these books

Del[ivere]d $x^{66}$ s[hillings] sent for by Mr Temple 17 March 1626

$<15$ December 1625>

$<$ [manicule] $>\sqrt{ }$ Item: Willot Athenae Franciscanus ${ }^{67} 8$ [octavo] + $=\sqrt{ }$ Florilegiu[m] Insulae SS sive vitae SS Hib[er]niae ${ }^{68}$ fol[io] habeo

\section{The That}

$<$ [manicule $]>0 \sqrt{ }$ Amb[rosio] Gozzea Cataloga Praedicatorum ${ }^{70}$

$=\sqrt{\text { P }}$ 8[octavo] habeo

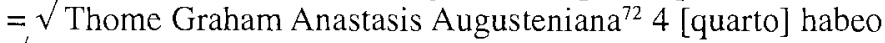

$\sqrt{ }$ Gallobelgica for the last $\mathrm{m}[\mathrm{ar}] \mathrm{t}$ habeo $^{73}$

$\sqrt{ }$ Catalogue of the last mart books habeo

$<$ [manicule] $>\sqrt{ }$ Chron[icon] ord[inis] Cisteric[iensis $]^{74}$

62 Italics indicate words inserted in different ink. Possibly William Hore of Harperstown, County Wexford. See John Burke, A genealogical and heraldic history of the commoners of Great Britain and Ireland (4 vols, London, 1838), iv, 718-19.

${ }^{63}$ Ware made notes from the manuscript in B.L., Lansdowne MS 418 , ff $47 \mathrm{r}-47 \mathrm{v}$. George Andrews is acknowledged at the end of the transcript.

${ }^{64}$ Presumably the register of the early thirteenth-century abbey of Great Conall. Sir Nicholas White lived in Leixlip, County Kildare. See G. E. Cokayne, et al. (eds), The complete peerage of England, Scotland, Ireland, Great Britain and the United Kingdom, extant, extinct or dormant (new ed., 13 volumes in 14, London, 1910-59; reprinted in 6 volumes, Gloucester, 2000), iii, 28.

${ }^{65}$ Bartholomew Downes, one of the king's printers in Ireland: Mary Pollard, A dictionary of the members of the Dublin book trade 1500-1800 (London, 2000), p. 166.

${ }^{66}$ I.e. ten.

${ }^{67}$ Henricus Willot, Athenae orthodoxum sodalitii Franciscani (Liege, 1598).

${ }^{68}$ Thomas Messingham. Florilegium Insulae Sanctorum seu Vitae et Acta Sanctorum Hiberniae (Paris, 1624).

${ }^{69}$ Thomas Hibernicus, Flores Omnium pene doctorum (Lyon, 1567).

${ }^{70}$ Ambrosio Gozzeo, Catalogus virorum ex familia Praedicatorum in litteris insignium (Venice, 1605).

${ }^{71}$ There are two possibilities for this entry which were penned by Petri Opmersensis (or Petrus Cratepoil). Either it was Omnium Archiepiscoporum Coloniensium ac Trevirensium Catalogus (Cologne, 1578) or Catalogus omnium totius prope orbis archiepisciporum episcoporumque (Cologne, 1596). The former is the more likely given Ware's pending publication on the lives of the archbishops of Cashel and Tuam in 1626.

${ }^{72}$ Thomas Gratianus, Anastasis Augustiniana in qua Scriptores Ordinis Eremitarum S. Augustini (Antwerp, 1613).

${ }_{73}$ Presumably a mart book from Belgium.

${ }^{74}$ This could be Aubert Miraeus, Chronicon Cisterciensis Ordinis (Cologne, 1614). 
$=\sqrt{ } \mathrm{Jo}[\mathrm{hn}]$ Selden Analecta Anglo-Brittanica ${ }^{75}$ habeo

$0 \sqrt{ }$ Nich[olas] F[it]z Herbert de Acad[emiae] oxon[iensis] ${ }^{76}$

Books to be sent for:

$=\sqrt{ }$ Polidorus vergill ${ }^{77}$ habeo

$=$ Hiberniae Judiciae habeo

$<$ [manicule $]>0$ Hibernia resurgens ${ }^{78}$ habeo

$<[$ manicule $]>=$ Rich. Verstegan Restitution of Engl[i] sh Antiquities $^{79}$ habeo + $=$ Philippi O Sulivan Historia Catholica Hiberniae ${ }^{80}$ habeo +

0 Historia ordinis Pradicator[um] p[er] Tho. Malvendam ${ }^{81}$

Mundus Jovialis p[er] Simonem Mareus ${ }^{82}$

$=$ Defensio Justinian[i] p[er] Tho. Ryves ${ }^{83}$ habeo

Aubert Miraeus De Cistercibus ${ }^{84}$

0 Constantia Catholica p[er] Christopher Henriques ${ }^{8.5}$

The Dre Jo selder ${ }^{86}$ habeo

Arcis Sammartiniae obsid in 1629 habeo ${ }^{87}$

Jo Kesoberg de mirsis anno 1621 phanomeia

De Cister? \&c p[er] Geor Schwabbach? [frail edges at the bottom]

\section{British Library, Additional MS 4821}

\section{[f. 236v]}

Books to be sent for

$<$ Mar. 1632>

Philippi Osulevani Zoiolomastix ${ }^{88}$

75 Jchn Selden, Analecton Anglo Britannicon (Frankfurt, 1615).

${ }^{76}$ Nicholas Fitzherbert, Oxoniensis in Anglia Academiae Descriptio (Rome, 1602).

77 Probably Polydore Vergil's Anglica Historia of which there were a number of editions.

${ }_{78}$ David Rothe, Hibernia resurgens, sive refrigerium antidotale adversus morsum serpentis antiqui (Rouen, 1621).

${ }^{79}$ Richard Verstegan, A restitution of decayed intelligence in antiquities concerning the most noble and renowned English nation (Antwerp, 1605). Verstegan was also known as Richard Rowlands.

${ }^{80}$ Philip O'Sullivan Beare, Historiae Catholicae Iberniae compendium (Lisbon, 1621).

${ }^{81}$ Thomas Malvenda, Annales Sacri Ordinis Praedicatorum (Naples, 1627).

${ }^{82}$ Simon Marius, Mundus Jovialis (Nuremburg, 1614).

83 Thomas Ryves, Imperatoris Justiniani defensio adversus Alemannum (London, 1626).

${ }^{84}$ Aubert Miraeus, Chronicon Cisterciensis Ordinis (Cologne, 1614).

${ }^{85}$ This must be a mistake by Ware as there is no book written by Crisóstomo Henriques with this title. He may have meant Henriques's Fasciculus Sanctorum ordinis Cisterciensis (Brussels, 1623).

${ }^{86}$ John Selden, The Duello, or Single Combat (London, 1610).

${ }^{87}$ Jacques Isnard, Arcis Sammartinianae obsidio et fuga Anglorum a rea insula (Paris, 1629). Italics indicate that this entry was written in pencil. This was obviously a later addition to the original list.

88 Philip O'Sullivan Beare, 'Zoilomastix' (unpublished manuscript). See T. J. O'Donnell, Selections from the Zoilomastix of Philip O'Sullivan Beare (I. M. C., Dublin, 1960). 
Philippi Osulevani Patriciana decas ${ }^{89}$

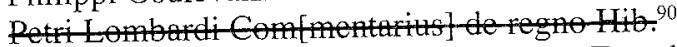

Florilegium Epigrammatum p[er] Thoma Farnaby ${ }^{91}$ $\sqrt{\text { B }}$

\section{Ex Catalogo Francofurtensi \\ pro nund[inis] Autumn 1633}

Andr[es] Reveti S.T.D. de origine Sabbathi Lugd[uni] Bat[avorum] in $12^{\circ} 93$ Arabia sive Arabu[m] leges Amsterdami in $16^{\circ} 94$

Tractat[u]s Michaelis Scoti de Secretis naturae Franc[ofurtensis] in $12^{\circ} 95$

Lib[er] futuris nundinis proditur ex eod[em] cat[alogo]

Nicholai Vedelii S.T.D. Arcanoru[m] Arminianor[um] par. 2 et 3 Lugd[uni] Bat[avorum] ${ }^{96}$

\section{Ex Catal[ogo] Fra[ncofurtensi] vern[um] 1638}

Analysis fidei p[er] Tho[mas] Baconu[m] al[ias] Southwellu[m] Soc. Jes. Antwerp in $4^{\circ} 97$

Codex regularu[m] et constituton[em] clericatiu[m] p[er] Aub[ert]. Miræu[s] fol[io] Ant[werp]. ${ }^{98}$

Stephani Simonini Silvae Urbanianx, seu gesta Urbani 8 Antier in $4^{\circ}$ onle $e^{99}$

${ }^{89}$ Philip O'Sullivan Beare, Patritiana Decas (Madrid, 1629).

${ }_{90}$ Peter Lombard, De regno Hibernice Sanctorum insula commentarius (Louvain, 1632)

91 Thomas Farnaby, Florilegium epigrammatum Graecorum eorumque Latino versu a variis redditorum (London, 1629).

92 [Lay Catholics of England], Declaratio Catholicorum laicorum Angliae circa authoritatem quam reumus Dominus Episcopus Chalcedonensis [Richard Smith] in eosdem vendicat (Antwerp, 1631).

${ }_{93}$ Andreae Riveti, Dissertatio de origine Sabbathi (Leiden, 1633).

${ }_{94}$ Gabriel Sionita and Joannes Hesranita, Arabia, seu Arabum vicinarumque gentium Orientalium leges, ritus sacri et profani mores, instituta et historia (Amsterdam, 1633).

95 Michael Scotus, Tractatus Michaelis Scoti, rerum naturalium perscrutatoris, de Secretis naturae (Frankfurt, 1615).

${ }^{96}$ Nicholaus Vedel, Archanorum Arminianismi pars tertia (Lyon, 1634).

97 Thomas Bacon, Regula viva seu Analysis fidei in Dei per ecclesiam nos docentis auctoritatem (Antwerp, 1638).

${ }^{98}$ Aubert Miraeus, Codex Regularum et constitutionum clericalium (Antwerp, 1638).

${ }^{99}$ Stephanus Simoninus, Silvae Urbanianae seu gesta Urbani VIII (Antwerp, 1637). 